\title{
Data Mining for Customers' Positive Reaction to Advertising in Social Media
}

\author{
Veera Boonjing \\ InternationalCollege, \\ King Mongkut's Institute of Technology Ladkrabang, \\ Ladkrabang, Bangkok, 10520, \\ Thailand \\ Email: veera.bo@kmitl.ac.th
}

\author{
Daranee Pimchangthong \\ Faculty of Businessm Administration, \\ Rajamangala University of \\ Technology Thanyaburi, Klong 6, \\ Thanyaburi, Pathum Thani, 12110, \\ Thailand \\ Email: daranee p@rmutt.ac.th
}

\begin{abstract}
The paper aims at 1) finding the most important factors influencing positive customer reactions and purchasing merchandises after seeing online social media advertising and 2) identifying characteristics of customer clusters having positive reaction, as well as of purchasing customer clusters, after seeing online social media advertising. Data from 370 respondents are collected by questionnaires using convenience sampling method. Attribute selection and clustering techniques are employed in data analysis to find important factors and identify customer clusters, respectively. It is found that there is a strong correlation between the reason for clicking advertisement on social media and the satisfaction with merchandise, and between purchasing merchandise online and saving information for further consideration. The findings also indicate the characteristics of "Product conscious" and "Price Conscious" clusters for customer's reaction and purchasing after seeing online social media advertising.
\end{abstract}

\section{INTRODUCTION}

$\mathrm{W}$ ITH high popularity of social media, several social media websites have been developed such as Line, Facebook, Twitter, etc. and the usage rate has increased every year. Social media has become a fast and easy way to reach people in almost every group categorized by age, occupation, and education etc. with less cost. The usage of social media is widespread in private and public environments. In the highly competitive business world, social media has become a source of large amounts of data that is extremely useful when data are analyzed properly. The results from analyzing data properly can be useful in variety of disciplines including education, business, politics, social, science, technology, etc.

Marketing campaigns with online advertising are one of the methods that businesses use for increasing purchasing motivation. Finding target customer characteristics and customer reactions to social media advertising helps to reach more customers and is useful information for a marketing campaign. Data mining is one of the known techniques to analyze data to find hidden information from a large amount of available data without having prior hypotheses. Data

This work was supported by King Mongkut's Institute of Technology Ladkrabang, Bangkok, Thailand. mining provides a variety of methods such as association, classification, clustering, etc. for analyzing data, but selecting a method to match with the objectives is a challenge.

The purposes of this study are to 1) find the most important factors influencing positive customer reactions after seeing online social media advertising, 2) find the most important factors influencing purchasing products advertised online, 3) identify customer clusters characteristics that have positive reaction after seeing online social media advertising, and 4) identify customer clusters characteristics that purchase merchandise after seeing online social media advertising.

The rest of paper is organized as follows. Section II gives a review of literature. Section III describes methodology. Results are given in Section IV. Section V concludes the paper and gives discussion.

\section{II.LITERATURE REVIEW}

Data mining has been defined as the process to extract knowledge from large quantities of data in order to discover meaningful patterns and rules [1]. Reference [2] defines data mining as the analysis of (often large) observational data sets to find unsuspected relationships and to summarize the data in novel ways that are both understandable and useful to the data owner. Reference [3] defines data mining as a process of knowledge discovery. Reference [4] summarized that data mining contains three key stages: finding patterns, interpreting them in order to check their usefulness, and finally using the patterns to solve business problems. The ultimate goal of data mining is to discover knowledge and it will be useful in several disciplines. In business, data mining is used for strategic benefit such as direct marketing, trend analysis, etc. In direct marketing, data mining is used for targeting people who are most likely to buy certain products and services. For trend analysis, data mining is used to determine trends in the marketplace [5].

Reference [4] explains that there are two main types of DM models as follows: 1) Predictive model: This model is constructed to predict a particular outcome or target variable. Commonly used predictive modeling techniques 
include multiple regression (for predicting value data), logistic regression (for response prediction) and decision trees (for rule-based value or response models). 2) Descriptive model: This model gives a better understanding of the data, without any single specific target variable. Commonly used descriptive techniques include factor analysis (to extract underlying dimensions from multivariate data), cluster analysis (for grouping a customer database into segments), and association analysis (for discovering relationships between items such as retail products).

A marketing campaign is a specifically defined series of activities used in marketing a new or changed product or service, or in using new marketing channels and methods. Marketing activities are efforts to increase awareness for a particular product or service. Social media is one of the most popular marketing channels due to the ability to reach large numbers of customers with low cost. Social media advertising helps businesses find new potential clients by using the users' own shared information to identify interest. Rather than re-actively targeting users who search for a certain term, social media advertising proactively targets relevant users before they even begin their searches.

Prior research that relates to the study topics were reviewed as follows: Reference [6] researched the factors that influence the recipients to open direct emails and make an action desired by the company and also studies whether and what elements in the email would influence them to buy the products or services promoted. The results are obtained based on a data mining analysis which includes clustering and classification processes and offer a guide on how organizations should design their email marketing communications in order to have higher response rates. Reference [7] researched on the value of social technologies in organizations based on the 'value focused thinking' approach. The findings highlight innovation of internal processes, creation of organizational identity and new business models, integrated business functions, as well as employee support to be important values of social technology enabled innovation in organizations. Reference [8] researched on the segmenting of consumer reactions to social network marketing. The purpose of the study is to understand how consumers may be segmented with respect to their reactions to social network marketing. The results identified five segments - Passive, Talkers, Hesitant, Active, and Averse -along with significant covariates such as information search, convenience, entertainment, age, and gender that predict membership.

\section{Methodology}

Several aspects related to the factors that influence a respondent to react and purchase a product or service after seeing social media advertising are explored from the literature review. Based on the literature review, the questionnaires are developed and distributed to people who used to purchase product or service through social media such as Facebook, Line, Instagram, etc. The questionnaires are composed of the three parts; the first part is about the demographic data of the respondents, the second part is about the respondent's reaction when seeing social media marketing campaigns, and the third part is open-ended questions about the respondent's opinion. The data has been gathered at the level of samples including 370 respondents aged less than 60 and being employees, freelancers, entrepreneurs, managers, and students. The data has been collected between January and April 2017 through an online survey by using the convenience sampling method.

The research directions include: determining the most important factors that influence the customers to have a positive reaction after seeing social media advertising; determining the most important factors influencing purchasing products that advertise online in social media; identifying the customers characteristics that have positive reaction after seeing social media advertising; and identifying the customer clusters characteristics that purchase merchandises after seeing social media advertising. The software used to analyze data is WEKA data mining software. The research employs an attribute evaluator called "CorrelationAttributeEval" for determining the most important factors with respect to class attributes. It also uses the "SimpleKMeans" clustering algorithm for grouping customers.

\section{Results}

The analysis results indicate that most of the respondents are students, females, aged 21-30, single, and educational level of Bachelor's degree, and average income less than 15,000 THB. Highest percentage on the usage of social media is Facebook, followed by Line and Instagram. The most purchasing are in fashion merchandise, followed by IT and software, and beauty and health merchandise. Spending per transaction is between 500 to $1,000 \mathrm{THB}$.

In order to identify the most important factors that influence the customers to have a positive reaction after seeing social media advertising, the class attribute called ReasonForClickingAdvertisementOnSocial Media is selected. The relation between the class attribute and the others is determined using CorrelationAttributeEval. The results present that for the customers, there is a strong correlation between the reason for clicking advertisement on social media and the satisfaction with merchandise (0.12727), special rewards (0.08522), not buying (0.0852), and link for searching on more details (0.08507). Other attributes are ranked below 0.07 .

The class attribute PurchasingMerchandiseOnline is selected to determine the most important factors influencing purchasing products with social media advertising. The relation between the class attribute and the others is determined using CorrelationAttributeEval. The results present that for the customers, there is a strong correlation between purchasing merchandise online and saving information for further consideration (0.13879), 
merchandise logo (0.10179), and immediately purchase if satisfied (0.09747). Other attributes are ranked below 0.09 .

The EM (Expectation Maximization) and "SimpleKMeans" clustering algorithms are used for grouping similar customers based on positive reaction after seeing social media advertising. The EM algorithm is used to identify the approximated cluster numbers. In this case, the result is 2 clusters. This value is used as a parameter for the "SimpleKMeans" algorithm. The algorithm results are presented in Table I.

Cluster 0: Most customers in this group save information for further consideration $(74 \%)$ and are interested in high percentage of discount $(64 \%)$ after seeing advertising in the social media. For this cluster, the advertising should emphasize on merchandise quality as well as price to create more positive reaction.

Cluster 1: Most customers in this group save information for further consideration $(70 \%)$, are interested in high percentage of discount (64\%) after seeing advertising in the social media, and are also interested in seeing text, image, and clip advertising (65\%). For this cluster, clip advertising may increase the customer's interest and create more positive reaction.

Clustering customers based on purchasing merchandises after seeing social media advertising is similar to clustering based on positive reaction after seeing social media advertising. The results are presented in Table II.

Cluster 0: This group of customers can be called "Product conscious." Most customers in this group save information for further consideration (74\%) after seeing advertising on the social media and purchase when satisfied with merchandise or services (55\%). Seeing text, image, and clip advertising is also interesting for this group (53\%). For this cluster, the advertising should emphasize on quality and brand to justify the price.

Cluster 1: This group can be called "Price conscious." Everyone in this group is concerned about price before purchasing merchandise. Interesting price (100\%) and high percentage of discount (71\%) will get these customers' attention. Customers in this group also like to save information for further consideration (65\%) and are interested to see text, image, and clip advertising (58\%). For this cluster, the opportunity to purchase at a low price should be emphasized on the advertisement online.

\section{V.CONCLUSION AND DISCUSSION}

Based on the findings from this research, e-commerce business should draw attention to the content that is emphasized in the advertisement online, due to some clusters
Table I. Customers cluster based on positive reaction after seeing social media advertising

\begin{tabular}{|c|c|c|c|}
\hline No. & Attributes & $\begin{array}{c}\text { Cluster 0 } \\
(94,25.4 \%)\end{array}$ & $\begin{array}{c}\text { Cluster } 1 \\
(276,74.6 \%)\end{array}$ \\
\hline 1 & $\begin{array}{l}\text { Interested in Seeing Advertisement on } \\
\text { Social Media: merchandise logo }\end{array}$ & 0.2128 & 0.0725 \\
\hline 2 & $\begin{array}{l}\text { Interested in Seeing Advertisement on } \\
\text { Social Media: text, image, and clip }\end{array}$ & 0.266 & 0.6522 \\
\hline 3 & $\begin{array}{l}\text { Interested in Seeing Advertisement on } \\
\text { Social Media: marketing campaign }\end{array}$ & 0.2766 & 0.1739 \\
\hline 4 & $\begin{array}{l}\text { Interested in Seeing Advertisement on } \\
\text { Social Media: link for searching more } \\
\text { details }\end{array}$ & 0.2234 & 0.0725 \\
\hline 5 & $\begin{array}{l}\text { Interested in Seeing Advertisement on } \\
\text { Social Media: package or merchandise }\end{array}$ & 0.0213 & 0.0254 \\
\hline 6 & $\begin{array}{l}\text { Interested in Seeing Advertisement on } \\
\text { Social Media: others }\end{array}$ & 0 & 0.0036 \\
\hline 7 & $\begin{array}{l}\text { Influence of Advertisement on Social } \\
\text { Media: immediately purchase if satisfy }\end{array}$ & 0.1596 & 0.1667 \\
\hline 8 & $\begin{array}{l}\text { Influence of Advertisement on Social } \\
\text { Media: saving information for further } \\
\text { consideration }\end{array}$ & 0.7447 & 0.6993 \\
\hline 9 & $\begin{array}{l}\text { Influence of Advertisement on Social } \\
\text { Media: sent it out for more comments }\end{array}$ & 0.0426 & 0.0326 \\
\hline 10 & $\begin{array}{l}\text { Influence of Advertisement on Social } \\
\text { Media: irritating and don't like adver- } \\
\text { tisement }\end{array}$ & 0.0532 & 0.0725 \\
\hline 11 & $\begin{array}{l}\text { Influence of Advertisement on Social } \\
\text { Media: not buying }\end{array}$ & 0 & 0.0254 \\
\hline 12 & $\begin{array}{l}\text { Influence of Advertisement on Social } \\
\text { Media: others }\end{array}$ & 0 & 0.0036 \\
\hline 13 & $\begin{array}{l}\text { Advertise Influence Buying: interesting } \\
\text { price }\end{array}$ & 0.3617 & 0.3659 \\
\hline 14 & $\begin{array}{l}\text { Advertise Influence Buying: popular } \\
\text { brand }\end{array}$ & 0.1383 & 0.1268 \\
\hline 15 & $\begin{array}{l}\text { Advertise Influence Buying: exciting } \\
\text { new merchandise }\end{array}$ & 0.0745 & 0.0507 \\
\hline 16 & $\begin{array}{l}\text { Advertise Influence Buying: Satisfaction } \\
\text { with merchandises or Services }\end{array}$ & 0.2872 & 0.3732 \\
\hline 17 & $\begin{array}{l}\text { Advertise Influence Buying: more refer } \\
\text { in social media }\end{array}$ & 0.1064 & 0.058 \\
\hline 18 & $\begin{array}{l}\text { Advertise Influence Buying: like market- } \\
\text { ing campaign }\end{array}$ & 0.0213 & 0.0217 \\
\hline 19 & Advertise Influence Buying: others & 0.0106 & 0.0036 \\
\hline 20 & $\begin{array}{l}\text { Marketing Campaign Influence Buying: } \\
\text { high percentage of discount }\end{array}$ & 0.6383 & 0.6449 \\
\hline 21 & $\begin{array}{l}\text { Marketing Campaign Influence Buying: } \\
\text { having complimentary }\end{array}$ & 0.1277 & 0.1522 \\
\hline 22 & $\begin{array}{l}\text { Marketing Campaign Influence Buying: } \\
\text { special rewards }\end{array}$ & 0.0319 & 0.0145 \\
\hline 23 & $\begin{array}{l}\text { Marketing Campaign Influence Buying: } \\
\text { having after sales service }\end{array}$ & 0.2021 & 0.1739 \\
\hline 24 & $\begin{array}{l}\text { Marketing Campaign Influence Buying: } \\
\text { others }\end{array}$ & 0 & 0.0145 \\
\hline
\end{tabular}


Table II. Customers cluster based on purchasing merchandises after seeing social media advertising

\begin{tabular}{|c|c|c|c|}
\hline No. & Attributes & $\begin{array}{c}\text { Cluster 0 } \\
(235,63.5 \%) \\
\end{array}$ & $\begin{array}{c}\text { Cluster 1 } \\
(\mathbf{1 3 5}, \mathbf{3 6 . 5 \%}) \\
\end{array}$ \\
\hline 1 & $\begin{array}{l}\text { Interested in Seeing Advertisement on } \\
\text { Social Media: merchandise logo }\end{array}$ & 0.0894 & 0.1407 \\
\hline 2 & $\begin{array}{l}\text { Interested in Seeing Advertisement on } \\
\text { Social Media: text, image, and clip ad- } \\
\text { vertising }\end{array}$ & 0.5362 & 0.5852 \\
\hline 3 & $\begin{array}{l}\text { Interested in Seeing Advertisement on } \\
\text { Social Media: marketing campaign }\end{array}$ & 0.2383 & 0.1333 \\
\hline 4 & $\begin{array}{l}\text { Interested in Seeing Advertisement on } \\
\text { Social Media: link for searching more } \\
\text { details }\end{array}$ & 0.1021 & 0.1259 \\
\hline 5 & $\begin{array}{l}\text { Interested in Seeing Advertisement on } \\
\text { Social Media: package or merchandise }\end{array}$ & 0.0298 & 0.0148 \\
\hline 6 & $\begin{array}{l}\text { Interested in Seeing Advertisement on } \\
\text { Social Media: others }\end{array}$ & 0.0043 & 0 \\
\hline 7 & $\begin{array}{l}\text { Influence of Advertisement on Social } \\
\text { Media: immediately purchase if satisfy }\end{array}$ & 0.1234 & 0.237 \\
\hline 8 & $\begin{array}{l}\text { Influence of Advertisement on Social } \\
\text { Media: saving Information for further } \\
\text { consideration }\end{array}$ & 0.7489 & 0.6444 \\
\hline 9 & $\begin{array}{l}\text { Influence of Advertisement on Social } \\
\text { Media: sent it out for more comments }\end{array}$ & 0.0468 & 0.0148 \\
\hline 10 & $\begin{array}{l}\text { Influence of Advertisement on Social } \\
\text { Media: irritating and don't like adver- } \\
\text { tisement }\end{array}$ & 0.0596 & 0.0815 \\
\hline 11 & $\begin{array}{l}\text { Influence of Advertisement on Social } \\
\text { Media: not buying }\end{array}$ & 0.017 & 0.0222 \\
\hline 12 & $\begin{array}{l}\text { Influence of Advertisement on Social } \\
\text { Media: others }\end{array}$ & 0.0043 & 0 \\
\hline 13 & $\begin{array}{l}\text { Advertise Influence Buying: interesting } \\
\text { price }\end{array}$ & 0 & 1 \\
\hline 14 & $\begin{array}{l}\text { Advertise Influence Buying: popular } \\
\text { brand }\end{array}$ & 0.2043 & 0 \\
\hline 15 & $\begin{array}{l}\text { Advertise Influence Buying: exciting } \\
\text { new merchandise }\end{array}$ & 0.0894 & 0 \\
\hline 16 & $\begin{array}{l}\text { Advertise Influence Buying: Satisfac- } \\
\text { tion with merchandises or services }\end{array}$ & 0.5532 & 0 \\
\hline 17 & $\begin{array}{l}\text { Advertise Influence Buying: more refer } \\
\text { in social media }\end{array}$ & 0.1106 & 0 \\
\hline 18 & $\begin{array}{l}\text { Advertise Influence Buying: like mar- } \\
\text { keting campaign }\end{array}$ & 0.034 & 0 \\
\hline 19 & Advertise Influence Buying: others & 0.0085 & 0 \\
\hline 20 & $\begin{array}{l}\text { Marketing Campaign Influence Buying: } \\
\text { high percentage of discount }\end{array}$ & 0.6043 & 0.7111 \\
\hline 21 & $\begin{array}{l}\text { Marketing Campaign Influence Buying: } \\
\text { having complimentary }\end{array}$ & 0.1362 & 0.163 \\
\hline 22 & $\begin{array}{l}\text { Marketing Campaign Influence Buying: } \\
\text { special rewards }\end{array}$ & 0.017 & 0.0222 \\
\hline 23 & $\begin{array}{l}\text { Marketing Campaign Influence Buying: } \\
\text { having after sales service }\end{array}$ & 0.2255 & 0.1037 \\
\hline 24 & $\begin{array}{l}\text { Marketing Campaign Influence Buying: } \\
\text { others }\end{array}$ & 0.017 & 0 \\
\hline
\end{tabular}

that are product conscious while others are price conscious. For the product conscious group, price does not matter as much for them and they decide to purchase based on satisfaction with the merchandise after thoroughly considering. Merchandise quality alone can get the product conscious group to purchase or have positive reaction after seeing online advertising in social media. For the price conscious group, they are looking for an interesting price and a high percentage of discount. Presenting interesting price will draw high attention from the price conscious group. However, both groups are interested in the advertisement online, and the advertisement that can draw customer's attention should provide interesting text, image, and clip advertisement. The advertisement should be attention-getting about the pricing so that it would convince the customers to click on the advertisement and continue to purchase the merchandise. The advertisement should also emphasize the high percentage of discount, which can draw attention from customers in both clusters that derive from positive reaction and lead to the purchasing of merchandise after seeing online advertising in social media.

The major limitation of the research consists in the low number of respondents (only 370), so this exploratory research should be followed by a conclusive one to verify the conclusions of the present research. Also, the majority of the respondents were students, aged 21-30, with low income and low spending per transaction, which may have influenced the positive reaction after seeing online advertising in social media.

Future directions of research may include: (1) using association techniques to determine rules related to positive reactions and purchasing, (2) adding some other information about respondents like time spent in front of the computer and time spent in using social network, and analyzing the influence of those factors on positive reactions and the purchasing of merchandise.

\section{REFERENCES}

[1] M. J. A. Berry and G. Linoff, Data Mining Techniques: For Marketing, Sales, and Customer Relationship Management 3rd ed., John Wiley and Sons Ltd., Publication, UK, 2011.

[2] D. J. Hand, H. Mannila and P. Smyth, Principles of Data Mining, MIT Press, Cambridge, MA, 2001.

[3] J. Han and M. Kamber, Data Mining Concepts and Techniques Second Edition, Morgan Kaufmann Publishers, United States of America, 2006.

[4] B. Leventhal, An introduction to data mining and other techniques for advanced analytics, Journal of Direct, Data and Digital Marketing Practice, 12(2), 2010, pp.137-153.

[5] M. Negnevitsky, Artificial Intelligence, A Guide To Intelligent Systems 3rd ed., Pearson Education Limited, 2005.

[6] R. I. Magos and C. A. Acatrinei, Designing Email Marketing Campaigns - A Data Mining Approach Based on Consumer Preferences, A nales Universitatis Apulensis Series Oeconomica, $17(1), 2015,15-30$.

[7] M. Singh and K. Peszynski, "Organisational Value of Social Technologies: An Australian Study, The Electronic Journal Information Systems Evaluation, 17(1), 2014, pp.088-099, available online at www.ejise.com.

[8] C. Campbell, C. Ferraro, and S. Sands, "Segmenting consumer reactions to social network marketing", European Journal of Marketing, 48(3/4), 2014, pp.432-452. 